\section{AMERICAN NOTES}

THE annual meeting of the National Academy of Sciences was held on the 18th of April last in the ro ms of the Smithsonian Institution, in Washington, and continued in session four days. A number of interesting communications wrere presented. A report was presen ed by the treasurer of the Academy in regard to the Bache bequest, in which it was stated that its present value was about 4r,000 clols, invested at $6 \mathrm{per}$ cent., and bringing an income of about 2,400 dols. a year. It may be remembered by some of our readers that Prof. A. D. Bache, the late head of the Coast Survey, left his property in trust to the National Academy of Sciences, after the death of Mrs. Bache, for purposes connected with the advance of science, appointing as special trustees Prof. Agassiz, Prof. Peirce, and Prof. Henry. The precise clisposition of this fund has not yet been determined upon, the bequest having fallen too recently into the hands of the society to make it necessary to come at once to a conclusion. - The ship Onivard arrived at New Bedford a few days ago, and her captain - Pulver-reports passing Sunday Island on the passage from Honululu, and states that the volcans near by, referred to in a previous number of cientific Intelligence, was at that time three miles long, and from 300 ft. to 400 t. high. The sulphurous vapou's extended around to a distance of three to four miles. He thinks that when the volcano becomes quiet there will be a good harbour betwe en it and the main land, where before there has been only an open roads:ead. The island is in latitude $29^{\circ}$ south, and in longitude $178^{\circ}$ west. The statement of Captain Pulver, according to the New Bedford Standard, is corroborated by other witnesses. - An examination has recently been made by an officer of the United States army of an old pueblo situated about twenty-five miles from the town of Socorro, on the Rio Grande. The walls of the buildings of this pueblo are composed of thin sandstone, heaped one layer upon another without mortar, and without any traces of beams or timber of any kind. The edifices seem to have been but one story high, and to have consisted of four separate buildings, arranged so as to form a hollow square with a fith a little outside of these. The longest range was over $200 \mathrm{ft}$. in length, and the whole five contained about two huntred ro:ms. Near the pueblo extensive silver mines have recently been discovered, and a town is to be laid out during the present year, the material for the houses to be derived from the ruins. There are evidences of ancient workings of these mines in the form of shafts now entirely filled up with earth, aithough it is probable that these do not antedate the period of the occupation of the comntry by the Spaniards. -According to late advices from South America, an unusually brilliant electric phenomenon was visible from Tacna, on the coast of Peru, early in March of the present year, around the snowy peak of Tacora, lasing for over two hours. The lightnings were of extraortinary shapes, and the thunders were of such intensity, and were heard over so wide an extent of country, as to completely terrify the population, unused to such exhibitions. This unwonted display was preceded by a slight shock of earthquake on the previous night. - According to the Comercio, of Lima, on the I2th of February, at Pitchican, an extraordinary meteor, of an oblong shape, and of a red colour, was seen to descend suddenly from the sky towarl the earth; and, as soon as it touched, an explosion occurred, leaving a dense cloud over the place, and knocking down a fence for about five hundred yards. Among the stones heaped around by this meteoric body were found recently dead fishes of different species, which were sul po:ed to have been lifted out of the river and dashed argainst the stones. - The cattle disease continues to spreac througheut South America, all efforts to resist its progress having been unavailing. At 1 he present time it is very prevalent in the Southern provinces of Chil and in the adjacent country. - The details of later advices from the Isthmus of Panama inclicate the discovery of a rather low water-shed between the Atlantic and Pacific, on the Isthmus of Darien, although the feasibility of constructing a canal is, after all, by no means well-established. As far as the engineering possibilities are concerned, the chance seems to be much nore favourable by way of Nicaragua, the result of a late invesigation by Mr. Sonnenstern, on behalf of the Nicaraguan Governm nut, serving to show that a ronte of 220 miles can be found cminecting the two ocenns, 196 of wlich is a.ready constituted by ihe riv: rs and lakes of the cimntry. leaving only twenty-four miles of land to be excavaled, with a maximum elevation of not more than twenty-six teet. A slight drawback, however, to the valne of this line is to be lound in the fact, stated in the same paper, that the harbour of San Juan del
Norte has been nearly filled up by a sand-bar, entirely preventing the entrance of vessels!

\section{SCIENTIFIC SERIALS}

THE Zeitschrift fïr Ethnologie for the present quarter begins with a critical paper on "Eihnological Classifications," especially those which rest on lannulage. The writer comments on the arbitrary character of the division of languages into "isolating," "aggintinating," and "inflecting," and contrasts the comparatively exhaustive knowledge of animal types on which zoological classifications depend, with the very scanty acquaintance which ethnologists possess of the great mass of languages beyond the Indo-European group. Exact knowledge of these latter highly complex and differentiated languages is, he argues, of very little use in tracing the origin and affinities of more primitive speech. It is suggested that peculiarities of language often depend on local characters of climate rather than on race. Thus, short words may be the result of a warm and lazy climate, like Siam, while, on the contrary, the chilly Indians of Athapascow take an athletic delight in calling their feet "choachastlsokai." Many interesting examples are given of Dog-Latin, Pigeon-Engglish, Chinook-French, and other bastard varieties of civilised languages, which appear to be modified in a certain definite way according to climate and to race. Here is an example of Monks' Latin of the date I 127. "Donent illis m Dominicis diebros carncm Mottotinum (Mouton) in autartis fertis cicerones, cum lardo." The second article in the same journal, by Franz Eligel, is on the national types and races of Tropical America. It contains an interesting account of the habits and characters of the Spanish Americans, the Creoles, Negroes, and Indians, with the various cross-breeds among them. But there is little addition to our knowledge of their anatomical and physiological peculiarities, and the whole description is written in a diffuse and affected style, including in one passage a very jrosaic travestie of verses from "Das Lied von der Glocke." A much shorter but valuable paper, by Adolf Hiibner, gives an account, with figures, of a great series of drawings he discovered on a flat slate rock in the Trans-Vaal Republic of South Africa. Indigenous wild animals of all kinds were, to judre from the specimens given, very fairly represented, with a few human figures, one holding a buw ; but no domestic animals were to be seen, nor was there any appearance of alphabetical or even picture-writing. The same writer gives also an account (with plans) of ancient Caffre fortifications in Mosalikatzi's kingdom.

In the Berlin Acadenny of Anthropolory, \&c., a sketch by Dr. H. H. Hildebrand was exhibited (and is reproduced in the Zeitschrift fiir Ethnolo: ie) of one of the urns with sculptured faces which have attracted so much attention in this Academy before. It was found in Cyprus. Other communications were on piledwellings in the Kuder See (Holstein), by L. Meyer; on an instrument of bone, about eight inches long, shaped like a knifeblade, and jagged along the edge, found in Mecklenburg; about fiteen feet deep, and covered by ten feet of chalk; on a buryingplace in East Prussia, which proved by the utensils discovered in the graves to have been used by Romans; on stone implements in East Greenland; and on the ethmological characters of the Turcos of the French Army, for the study of which recent events have offered unusual facilities. At a subsequent meeting of the Academy, Prof. Virchow read a paper on the use of tibice and and other bones as skates in early times; and Herr Jagor one on the discovery of kitchen middens in the Andaman Isles.

In a reprint from the Archaologia (vol. xlii.) Prof. Rolleston gives an interesting account of his researches in a Roman-British cemetery at Frilford, near Abingdon. Superficial to the more ancient interments, which were mostly in coffins and belonged to Christian times, were found later remains of the Saxon Pagan period. The latter were placed promiscuously, the former with more or less orientation, and the fact that the direction of the grave usually deviates towards the south is ingeniously explained as due to the majority of deaths having taken place then, as now, in the winter quarter of the year, when the sun would rise south of the due east. From the character of the skulls, and the urns, weapons, nails, \&c, found in the graves, various important conclusions are drawn as to the social cindition of this country during the obscure peritid between the departure of the R.mans and the conversion of the Sixons; and the whole paper is illustrated by a curious and felicitons erudition which reminds the reader of the account of a Roman cemetery at OId Walsingham, given in the "Hydriotaphia" of Sir Thomas Browne." 